\title{
THE DYNAMICS OF CONTEMPORARY ISLAMIC THINKING AND THE ROLE OF EDUCATION: Islamic Fundamentalism, Opponents, and Hybrid Thought
}

\author{
Irham \\ Universitas Islam 45 Bekasi, Indonesia \\ irham.muu@gmail.com \\ Zakaria Husin Lubis \\ Istitute Perguruan Tinggi Ilmu al-Qur'an Jakarta, Indonesia \\ zakarialubis@ptiq.ac.id
}

\begin{abstract}
This article is written to explain the dynamics of contemporary Islamic thought and the role of Islamic education as one of its supports. The dynamics of Islamic thought are diverse but have the same character that is opposite thoughts and thoughts that seek common ground. The opposite thoughts depicting here are Islamic fundamentalism and liberalism. Then the thought that seeks common ground here is called hybrid thought. This article is a literature review by utilizing the findings in the previous study formulated into new findings that have not been discussed in the previous study. This paper concludes that the dynamic of contemporary Islamic thought with its character grows not from the role of Islamic education. Although it cannot be denied that the role of Islamic education in this case is not the only one, because there are other factors such as historical, political, technological, globalization, modernization, social and cultural contexts. Fundamental Islamic thought can be sustained and developed by an ideological-purist Islamic education model (manhaj salafi). Likewise, the form of liberal thinking and development by an academic-scientifically oriented, rational and secular model of education. Hybrid forms of thought that are
\end{abstract}


supported by a moderate-inclusive education model that develop textual-contextual methods, balance nasal sources, reason and intuitive, accommodate old and modern traditions that are still relevant and do not conflict with religious values.

الملخص : هذه المقالة تقصد لشرح ديناميات الفكرة الاسلامية المعاصرة و دور التعليم

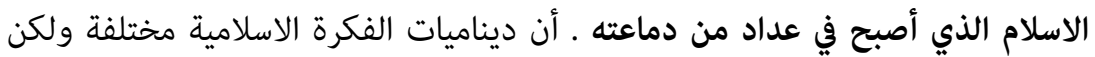

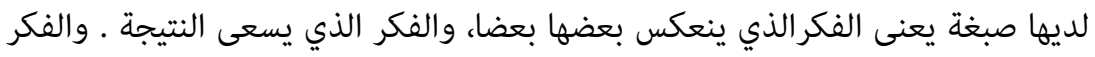

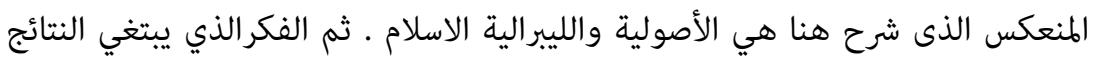

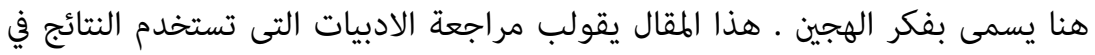

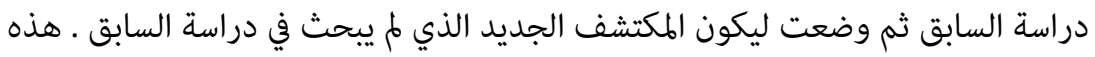

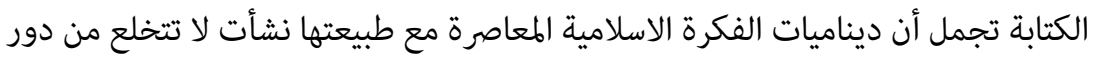

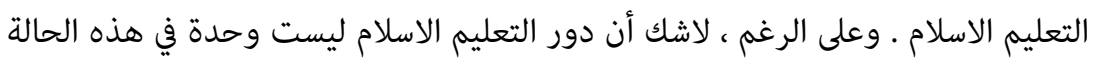

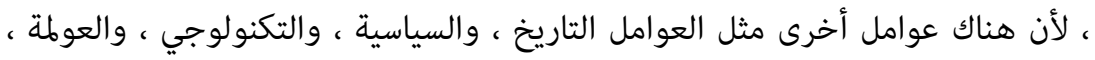

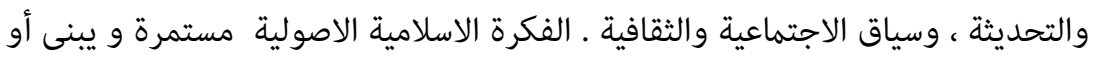

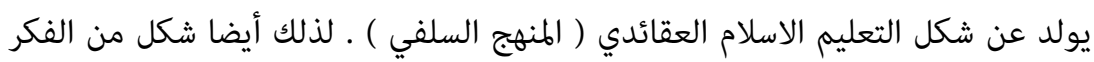

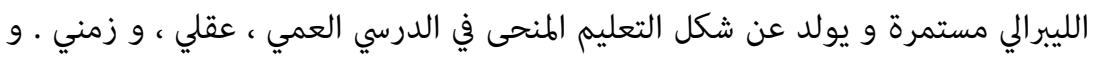

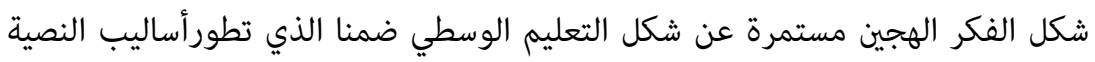

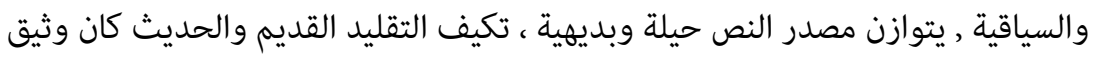

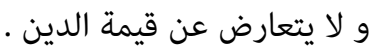

Abstrak: Artikel ini bermaksud untuk menjelaskan dinamika pemikiran Islam kontemporer dan peran pendidikan Islam sebagai salah satu faktor penopang. Dinamika pemikiran Islam sangat beragam, namun memiliki karakter yang sama yaitu pemikiran yang saling berlawanan dan pemikiran yang mencari titik temu. Pemikiran yang saling berlawanan yang dijelaskan di sini adalah fundamentalisme dan liberalisme Islam. Kemudian pemikiran yang mencari titik temu di sini disebut dengan pemikiran hybrid. Artikel ini merupakan kajian pustaka dengan memanfaatkan temuan-temuan dalam kajian terdahulu lalu dirumuskan menjadi temuan baru yang belum dibahas pada kajian sebelumya. Tulisan ini menyimpulkan bahwa dinamika pemikiran Islam kontemporer dengan karakternya tumbuh berkembang tidak terlepas dari peran pendidikan Islam. Meskipun tidak dipungkiri bahwa peran pendidikan Islam dalam hal ini bukan satu-satunya, 
karena masih ada faktor lainnya seperti faktor sejarah, politik, teknologi, globalisasi, modernisasi, konteks sosial dan budaya. Pemikiran Islam fundamental dapat ditopang dan dilahirkan oleh model pendidikan Islam idiologis-puris (manhaj salafi). Begitu pula bentuk pemikiran liberal ditopang dan dilahirkan oleh model pendidikan yang berorientasi akademik-ilmiah, rasional dan sekuler. Bentuk pemikiran hybrid ditopang oleh model pendidikan moderat-inklusifyang mengembangkan metode tekstual-kontekstual, menyeimbangkan sumber nas\} $\}$, akal dan intuitif, mengakomodasi tradisi lama dan modern yang masih relevan dan tidak bertentangan dengan nilai agama.

Keywords: Fundamentalism, Liberalism, Hybrid Thought, Islamic Education, Islamic Thought.

\section{INTRODUCTION}

The dynamics of contemporary Islamic thought have various styles and cannot be separated from the intersection of Islam and modernism and the process of globalization. The dynamics that develop have certain patterns, namely patterns of thinking that are always face to face and thoughts that bring them together / middle way thinking. This pattern has occurred in the history of Islam in the past, for example the history of the debate between the Shia, Khawarij and Sunni groups, then groups with qadariyah and jabariyah theology. Theology of ahlun al-sunnah wa al-jama > 'ah is a school that takes the middle ground from the previous debate. So in the history of the dynamics of Islamic thought, there have always been groups of thought that have clashed and there have been groups of thought that have tried to find common ground.

This article examines the face-to-face thinking in contemporary dynamics, namely Islamic fundamentalism and Islamic liberalism. Then between these two contradictory thoughts there are thoughts that are hybrid in nature with their characters open, objective, textual as well as contextual, moderate, and accommodative for tolerance of differences, seeking common ground and synthesizing. The development of this dynamic is certainly inseparable from the 
historical roots of the past that have occurred, but this paper does not focus on this theme.

Many previous studies have been carried out related to Islamic fundamentalism or liberalism and the differences between the two. Writings that specifically study Islamic fundamentalism, for example, were written by Hannabus who tried to explain from a historical perspective. ${ }^{1}$ Next written by Sahid Hm. which explains that khilafahism is an important basis of Islamic fundamentalism because it makes them obliged to fight for it. ${ }^{2}$ Another theme is related to the potential tendency of fundamentalism to lead to radical movements / extremism. Studies leading to it, for example, were written by La Ode Anhusadar and Yee $\mathrm{Lak}^{3}$ and which specifically discusses the configuration of radical Islam, especially in Indonesia, was written by Masdar Hilmy and Abd A'la. ${ }^{4}$ The writings that link the three relationships between Islamic fundamentalism, the state and global citizenship are written by Asep Muhammad Iqbal and Zulkifli. ${ }^{5}$ These writings represent writings on the theme of Islamic fundamentalism, of course there are many others. In general, the study of this theme still makes ideology, past history and politics as factors of background including. As for the factor of religious education with

1 Stuart Hannabuss, "Historical Dictionary of Islamic Fundamentalism (2nd Edition)," Reference Reviews 32, no. 7/8 (September 17, 2018): 10-12, doi: 10.1108 / RR-09-2018-0133.

2 Sahid Hm, "Contesting Caliphate: Opposition of Indonesian Fundamentalist Groups to ISIS Caliphate,” Journal Of Indonesian Islam 8, no. 2 (December 1, 2014): 185-208, doi: 10.15642 / JIIS.2014.8.2.185-208.

3 LaOde Anhusadar, "The Potential of Fundamental Islamic Radicalism in Tourist Destination Areas in Wakatobi Regency," Al-Tahrir: Journal of Islamic Thought 18, no. 1 (May 30, 2018): 23-40, doi: 10.21154 / altahrir.v18i1.1122; Yee Lak Elliot Lee, "Behaviorist Fundamentalism Turns Radical: ETIM / TIP's Islamic Fundamentalist Representations and Narratives," Journal of Middle Eastern and Islamic Studies (in Asia) 9, no. 4 (December 2015): 85-99, doi: 10.1080 / 19370679.2015.12023274.

4 Masdar Hilmy, "The Configuration Of Radical Islamism In Indonesia: Some Contemporary Assessments and Trajectories," Al-Tahrir: Jurnal Pemikiran Islam 14, no. 1 (May 1, 2014): 1, doi:10.21154/al-tahrir.v14i1.84; Abd A'la, "The Genealogy Of Muslim Radicalism In Indonesia: A Study of the Roots and Characteristics of the Padri Movement," Journal Of Indonesian Islam 2, no. 2 (December 1, 2008): 267-99, doi:10.15642/JIIS.2008.2.2.267-299.

5 Asep Muhammad Iqbal and Zulkifli Zulkifli, "Islamic Fundamentalism, Nation-State and Global Citizenship: The Case of Hizb Ut-Tahrir," Indonesian Journal of Islam and Muslim Societies 6, no. 1 (June 1, 2016): 35, doi: 10.18326 / ijims.v6i1.35-61. 
the pattern specified as a trigger of Islamic fundamentalism has not been much studied

The study that discusses the theme of Islamic liberalism, for example, was written by Erowati Dewi, who tried to elaborate on the issues that became the concentration of liberal Islamic groups. His findings indicate that Islamic thought is the dynamic of Islamic political thought as opposed to Islamic fundamentalism. ${ }^{6}$ Then there is the writing of Badarus Syamsi which tries to find the difference between fundamental Islam and liberal Islam. ${ }^{7}$ The same theme was also written by Ahmad Munjid, who showed that these two opposing thoughts were both the result of the intersection of Islam and modernism. ${ }^{8}$ Based on the existence study, Islam liberalism basically grow up as a response to the phenomenon of Islamic fundamentalism in the modern context. Studies that associate with the pattern of religious education as a trigger of its growth and development is still little discussed.

The previous writings relating to either fundamentalism or Islam liberalism is part of the dynamics of contemporary Islamic thought. This writing which try to face and search for the differences and the trigger has been widely implemented. It's just the theme of a study that tried to parse it simultaneously with the Islamic thought of the middle way as part of the dynamics of contemporary Islamic thought very hard to find. Moreover, if it is combined with the discussion of the role of Islamic education as a center of current thought. Therefore, this article tries to analyze in order to contribute to the view that contemporary Islamic thought does not always face to face but there is the thought of the middle way, which can then bring up the thought of a hybrid. The contribution of others, this study will show that the dynamics of contemporary Islamic thought is not separated from the role of Islamic education. In the end the findings of this article

6 Erowati Dewi, "Islam Liberal Di Indonesia (Pemikiran Dan Pengaruhnya Dalam Pemikiran Politik Islam Di Indonesia," JIIP: Jurnal Ilmiah Ilmu Pemerintahan 2, no. 2 (January 23, 2018): 18-32, doi:10.14710/jiip.v2i2.2119.

7 Badarus Syamsi, "Perbedaan Corak Pemahaman Agama Antara Fundamentalisme Dan Liberalisme Serta Dampaknya Bagi Timbulnya Konflik Keagamaan," Al-Tahrir: Jurnal Pemikiran Islam 14, no. 1 (May 1, 2014): 73, doi:10.21154/al-tahrir.v14i1.120.

8 Achmad Munjid, "Militant And Liberal Islam: The Unwanted Twin Children of Modernization Â" An Indonesian Experience, ”Journal Of Indonesian Islam 3, no. 1 (June 1, 2009): 35, doi: 10.15642 / JIIS.2009.3.1.35-68. 
can be a recommendation for Islamic education so can see the back orientation of religious education that have been developed.

\section{THE DYNAMICS OF THE ISLAMIC FUNDAMENTALISM AND ITS OPPONENTS}

Islamic fundamentalism and Islamic liberalism are the two thoughts that opposite each other. Both of them criticize each other and look for each other's shortcomings. In the context of Indonesia, the debate over both of them have long been the case, for example Adian Husaini published a book attacking the views of the islamic liberalism although the argument is also easily disproved, and vice versa. Why it happened like that, more details, let's understand two thoughts that crossed it. Islamic fundamentalism and liberalism Islam are the two thoughts that repel. Both of them criticize each other and look for each other's shortcomings. In the context of Indonesia, the debate over both of them have long been the case, for example Adian Husaini published a book attacking the views of the liberal Islam ${ }^{9}$ though the argument is also easily refuted, and vice versa. Why it happened like that, more details, let's understand two thoughts that crossed it. Islamic fundamentalism is a term that has a meaning evolutive. Initially, fundamentalism was understood as merely a religious sect that wanted to be like the diversity of the early generations of Islam. Then this conception continues to shift to things that have to do with terrorism, extremism, jihadism and khilafahism.

The initial understanding, for example, was explained by Leonard Binder. He defines Islamic fundamentalism as a 'religious sect' that is romanticized towards early Islam. Islamic doctrine is believed to be complete, perfect and covers all the problems of life. God's laws have governed the entire universe without any problems that have escaped his notice. ${ }^{10}$ In religious practice, these circles are synonymous with formal legalists, considering absolute sharia at the social level which is no longer possible to change or to reinterpret it by adjusting current conditions. ${ }^{11}$ Some people call this understanding as conservative or

9 Adian Husaini and Nuim Hidayat, Islam Liberal: Sejarah, Konsepsi, Penyimpangan, Dan Jawabannya (Jakarta: Gema Insani Pres, 2002).

${ }^{10}$ Leonard Binder, Religion and Politics in Pakistan (University of California Press, 1961), p. 71.

${ }^{11}$ Daniel Pipes, In the Path of God: Islam and Political Power (New Brunswick, NJ: Transaction Publishers, 2002), p. 124-126. 
traditional Islam, although of course there are those who disagree, because each has its own criteria.

Meanwhile, the second understanding is still related to the previous understanding, which is accompanied by an understanding of terrorism, jihadism and the caliphate with emotional and political connotations. This explanation is now becoming popular among scientists. ${ }^{12}$ The characteristic of Islamic fundamentalism is the belief in the establishment of an Islamic caliphate state as part of a religious obligation. They share the view that the khilafah has a strong textual-normative foundation, so it must be fought for. However, the adherents of Islamic fundamentalism in various parts of the world have diversity in the implementation of these beliefs, there are those that justify all means (extreme) and there are those who tend to be more lenient by promoting dialogue. ${ }^{13}$ So that when viewed from its actions, this fundamentalist group has various forms, ranging from the hardest to the softest.

It cannot be denied that the potential to become radical in fundamentalism is very close. Even fundamentalism can be a bridge to lead to it. This can happen if it is driven by factors that influence it, for example; religious emotions; religious ideology, political pressure; media announcement; the ideology of $j i h a>d$, and the like. ${ }^{14}$ On the other hand, there are those who state that Islamic fundamentalism in the era of 4.0 is often considered radical because they want all forms of early Islamic behavior to be re-applied in their ways. ${ }^{15}$ Even though these views are different, one is still potential and the other states that it has become, but the opinions of both have the same tendency towards it.

If examined more deeply, there are similar slices between fundamentalism and religious radicalism, even though fundamentalism is said to be the opening door. Basically, radical Islamic ideology

\footnotetext{
${ }^{12}$ Hannabuss, "Historical Dictionary of Islamic Fundamentalism (2nd Edition)."

${ }^{13} \mathrm{Hm}$, "Contesting Caliphate."

${ }^{14}$ Anhusadar, "Potensi Radikalisme Islam Fundamental Di Daerah Tujuan Wisata Di Kabupaten Wakatobi."

${ }^{15}$ Anita Oray, "Religious Fundamentalism and Radicalization," March 2015, pag. 1-8, https://www.europarl.europa.eu/EPRS/EPRS-briefing-551342-Religiousfundamentalism-and-radicalisation-FINAL.pdf. Yee Lak Elliot Lee, "Behaviorist Fundamentalism Turns Radical: ETIM / TIP's Islamic Fundamentalist Representations and Narratives," Journal of Middle Eastern and Islamic Studies (in Asia) 9, no. 4 (December 2015): pag. 85-99, doi: 10.1080 / 19370679.2015.12023274.
} 
has characteri s tics including; religious ideology is derived from religious text s (al-Qur'an and hadith); socio-political setting; and the relationship between textual understanding and socio-political issues. ${ }^{16}$ This characteristic certainly shows that the problems of fundamentalism and religious radicalism are complex which are not only seen from the point of view of religious doctrine.

Researchers arg ue about the source of the emergence of this idea. Some argue that Islamic fundamentalism is characterized as a reaction to global conditions related to economics and politics, especially global powers that come from the West. Fundamentalists try to reject this power because they are considered to have eroded their traditions. However, there are those who deny this view by stating that Is 1 amic fundamentalism actually takes part in the phenomenon of g lobalization itself. The Islamic fundamentalism movement accompanied by utopian ideology is part of the power of globalization which represents the return of the role of religion with its character of rejecting the validity of the nation state and the vision of global citizenship by establishing an Islamic caliphate state. Hizbut Tahrir Indonesia (HTI) is an example of this phenomenon. ${ }^{17}$ This debate shows that the emergence of religious fundamentalism has various motivations and methods. Each case is different because of the diversity behind which they grow in motion.

If you read the history of radical movements in the name of religion, it will be seen that their growth was not accompanied by a similarity in social situations or dimensions. This is because the social settings are different and each movement has its own peculiarities. However, the movements that lead to religious radicalism have the same spirit, namely the existence of a deep determination to believe as the purest $\mathrm{v}$ e rsion of Islam which subsequently manipulates religious symbols to realize their political agenda. One such case is the Padri movement in West Sumatra and the Wahhabiah movement in Arabia. ${ }^{18}$

In essence, Islamic fundamentalism is part of the representation of religious ideology in which there are movements, ideas, or

\footnotetext{
${ }^{16}$ Hilmy, "The Configuration Of Radical Islamism In Indonesia."

${ }^{17}$ Iqbal and Zulkifli, "Islamic Fundamentalism, Nation-State and Global Citizenship."

${ }^{18}$ A'la, "The Genealogy Of Muslim Radicalism In Indonesia."
} 
understandings by bringing Islamic aspirations into state and social practice. This form of diversity became a systematic and organized movement that emerged in the 19th century in Arabia and Egypt, although its seeds have been around for a long time. This movement continues to experience development, especially in relation to the relationship to the state whose goal is to carry out the Islamic political ideology. There are at least three different types of relationships in this movement, namely; a relationship with a scriptual-rational style that gives birth to textualistic and literalistic forms of understanding; relations that tend to be idealist-realist; and formalist-substantive relationships. ${ }^{19}$

The thought that dealing with Islamic fundamentalism is the thought of islamic liberalism. The emergence of liberal Islam was initiated by Muslim scholars who were nervous about the decline of Islam starting in the era of 3.0 to 4.0. All technology is controlled by European countries which in fact are mostly non-Muslim, coupled with their behavior towards a very Islamic environment compared to countries with more Muslims. These considerations are among the material for reflection by Liberal Islam groups who want the progress of Islam and leave things that can hinder it. ${ }^{20}$

The idea of establishing an Islamic state will always be rejected by liberal Islamic development groups. This group focuses its attention on issues of pluralism, democracy and equality. In the history of Islamic political thought the two of them continued to clash. ${ }^{21}$ The perspective of the liberal Islam group is antiliteralism or anti-textualism. This method is a harsh criticism of fundamentalism or radicalism in understanding religious teachings or doctrines in the spirit of defending God which can produce rigid

${ }^{19}$ Abdul Chalik, "Fundamentalisme Dan Masa Depan Ideologi Politik Islam," Islamica: Jurnal Studi Keislaman 9, no. 1 (2014): 54, doi:10.15642/ islamica.2014.9.1.54-80.

${ }^{20}$ Since 9/11 Islamic thinkers have tried to promote moderate Islam to counter extremist radic al Islam. The impact of this incident was that Western countries saw Islam as a harsh religion, resulting in Islamaphobia. Since then, Muslims have emerged who reconcile their thinking with Western thinking, they believe that Islamic teachings can go hand in hand with modernity.Zaheer Kazmi, "The Limits of Muslim Liberalism,” Muslim Institute, accessed May 22, 2020, https://musliminstitute.org/ freethinking/religion/limits-muslim-liberalism.

${ }^{21}$ Dewi, "Islam Liberal Di Indonesia (Pemikiran Dan Pengaruhnya Dalam Pemikiran Politik Islam Di Indonesia." 
and rigid understanding. Both of them feel the truest in their belief in understanding religion which is always opposite. ${ }^{22}$ The difference between these two schools of thought occurs from all sides, from the ways or methods of understanding Islam, the epistemological basis used to the products of thinking and religious ways.

The phenomenon of the existence of Islamic fundamentalism or Islamic militancy and also the opponent of thought, namely Islamic liberalism, is a result of the intersection of Islam and modernity. Both are very contrasting in religion and have the principle of life, even the development of both of them are both fast along with the project of modernity. However, it should not be forgotten that both have past roots that are embedded in the struggles of theology, history, sociopolitics and ulama thought. These two phenomena basically indicate the dynamics among Muslims in negotiating between religion and modernity. ${ }^{23}$

This dynamic has occurred in past Islamic history, especially when there was an intersection of Islamic thought with other thought traditions. This happened at a time when Islam made a massive expansion outside the Hejaz region, especially the Hellenization areas (Egypt, Syria, Iran and Iraq). The Hellenization area long before Muhammad SAW preached Islam there had been an exchange and confusion of ideas in the region. The hegemony of the thoughts of the Greek philosophers succeeded in introducing philosophy in this area so that there was acculturation with the local culture.

At the peak of Islamic glory, namely the Umayyad era, the expansion of Islam stretched from the east in parts of Asia, south in parts of Africa and to the west of Andalusia. Judging from the strength of the military, this daulah makes non-Muslims unable to attack areas controlled by Muslims so that the transformation of war turns into a war of thought (gazwah al-fikr). Christian communities living in Muslim areas try to launch attacks through thinking by having a dialogue about tawhid to Muslim communities because with this non-Muslims hope to win and disturb Muslim beliefs.

It was from these religious dialogues and debates that Muslims were first converted to the benefits of logic and also to attack the

\footnotetext{
${ }^{22}$ Syamsi, "Differences In Religious Understanding Between Fundamentalism And Liberalism And Its Impact For The Arrival Of Religious Conflict."

${ }^{23}$ Munjid, "Militant And Liberal Islam."
} 
religions of other parties. They have experienced for themselves how the weapons of logic and philosophy are used by non-Muslims to attack Islamic teachings. ${ }^{24}$ As a result of this religious debate, a Muslim community known as the kalam sect appeared to protect Islamic teachings from logical attacks launched by non-Muslim circles. Figures such as Jahm Ibn Safwan (w.128H / 746M) who was famous for his Jabariyah understanding, Wasil Ibn Ata '(w.131 H / 749 AD) who was famous for his Mu'tazilah understanding, Ma'bad al-Juhani (w. $80 \mathrm{H} / 699 \mathrm{M}$ ) which is famous for its Qodariyah understanding and so on. Judging from the historical journey between these two understandings at the political level, they are very ambivalent, sometimes in line if they are in accordance with the prevailing ideology of the regime and sometimes they are not in line if they are not in accordance with the prevailing ideology of the regime. For example Ahmad bin Hambal whose thoughts differed from the regime in power at that time caused him to be sentenced to imprisonment by the Abbasid caliph, Al-Ma'mun. Furthermore, when Mutawakil came to power Ahmad bin Hambal was released. ${ }^{25}$ This kind of dynamic often occurs between the ulama themselves and the ulama with the ruling political regime.

Recently, there have been scholars who have become a middle way or able to synthesize from the thoughts of previous scholars. Imam Shafii is one of those whose thoughts are able to bring together previous thoughts. However, not all of these are well received by different groups. Imam Shafi'i was one of the victims of the understanding of the opposing followers of Maliki, then he was attacked with a padlock by Asyhab bin Abdul Aziz which caused him illness for a few days and finally died around $204 \mathrm{H} .{ }^{26}$ So the products of rigid, flexible, rational, textual, or moderate thoughts

${ }^{24}$ Abdul Aziz Dahlan, Pemikiran Falsafi dalam Islam (Jakarta: Djambatan, 2003), hal. 20.

${ }^{25}$ Many stories circulate about Ahmad bin Hanbal when he was put in prison because of differences in understanding with the regime, one of which is about the Quran, whether it is a creature or God's word. Abdul Aziz al-Rajihi, Syarh Usul alSunnah li Imam Ahmad bin Hamal (Riyad: Dar tauhid, 1433), p. 54-55, https://www. noor-book.com/كتاب-شرح-أصول-السنة-للإمام-أحمد-بن-حنبل-pdf-pdf. Ibn al-Jawzi, Manaqib alImam Ahmad bin Hambal (Mișr: Maktabat al-Khānjī, 1979), p. 397.

${ }^{26}$ Yaqut al-Hamawi al-Rumi, Mu'jam al-Udabā: Irsyad al Arif ila Ma'rifati al-Adib (Beirut: Dar Gharbi al-Islami, 1993), http://archive.org/details/waq45344. Ibn Hajar al-'Asqalānī, Tawālī Al-Tạsīs (Beirut: Dār al-Kutub al-'Ilmiah, 1986), 
have basically occurred in the past, between those who are hostile and those who seek a middle way. The group in the middle of the road was not separated from rejection either. Islamic fundamentalism and liberalism today have the same slices as past history, although the context is different. This past history can be called the seed of these two schools of thought.

If we observe closer that the dynamics of Islamic fundamentalism and liberalism from the above discussion layed in the process of understanding religion. This process can be seen in terms of the methodology in understanding the Qur'an and hadith, the epistemological basis used, the understanding of the relationship between religion and the state and the response to the socio-cultural context (modernization). Specific discussions about the differences in how to understand Islam and those related to hybrid Islamic thought will be explained in the next section. So in essence, the process of understanding religions that are contradictory or synthetic / hybrid, then determines one's Islamic and religious thinking.

\section{EPISTEMOLOGICAL CONFLICT}

The world is now moving in a nuance called an industri 4.0. This world is marked by the existence of information and digital technology as the basis for humans to fulfill their lives, including utilizing digital literature for learning purposes. In this era, everyone is free to access information without time and space limits. All forms of knowledge are often obtained in cyberspace without having to involve the presence of teachers as in the real world. ${ }^{27}$ With increasingly sophisticated technology and information, the process of globalization becomes faster, including the globalization of religion.

In this context, both religious fundamentalism and its opposites find a moment, so that the gap becomes even wider. Fundamentalist and liberal doctrines in the era of 4.0 are increasingly being carried out by social media activists with various goals. Print and electronic media have become a means of polemicizing these two views. The

p. 86. “Al-Shafi'i," in Wikipedia, July 31, 2020, https://en.wikipedia.org/w/index. php?title=Al-Shafi\%E2\%80\%98i\&oldid=970506984.

${ }^{27}$ Sven-Vegard Buer, Jan Ola Strandhagen, and Felix TS Chan, "The Link between Industry 4.0 and Lean Manufacturing: Mapping Current Research and Establishing a Research Agenda," International Journal of Production Research 56, no. 8 (April 18, 2018): p. 2924-2940, doi: 10.1080 / 00207543.2018 .1442945$. 
growth of publishers among fundamentalists nurtured the sowing of puritan ideas in society, especially the student community in state public universities. A normative and apologetic style of writing characterizes most of the works that were born among fundamentalists. These works are aimed at arousing a religious spirit and consistently implementing Islamic teachings.

The polemic waged by fundamentalists against liberal Islam shows the struggle between puritanism and relativism in religion. This polemic stems from differences in the basic approaches of Islamic studies among Muslims. The polemics launched by fundamentalists are not only related to liberal Islam, but also against fellow fundamentalists and against non-Muslims. The polemic was held through various means, including magazines, books, and open debates, which were then documented on a $\mathrm{CD} .{ }^{28}$

The argument commonly used by fundamentalists against their opponents, especially the liberal ones, is apologetic. The beautiful jargon that is spread by packing a relativism understanding of truth that looks logical and attractive is always rejected by him. Such beautiful jargon is like the expression "differentiate between religion and religiosity", "religion is absolute, while religious thought is relative", "humans are relative, therefore all thoughts are products of human reason are also relative", "interpretation is a product of human reason, so that it cannot be absolutely absolute revelation itself "," as long as humans are still human, then the results of their thinking remain partial, contextual, and may be wrong ". ${ }^{29}$

Fundamentalism and Islamic liberalism are two contrasting religious streams and are always in conflict. Each of them has a claim to truth on the basis of their religious teachings. Both have fundamental differences in their approaches to understanding religion. Islamic fundamentalism seeks to restore pure religious teachings with a textual-literal approach. Meanwhile, Islamic liberalism rejects this because it is considered to trigger violence and underdevelopment of Muslims. The approach used is the contextualization of religious

${ }^{28}$ Jainal, "Polemik Metode Pemikiran Islam Fundamental Dan Liberal Tentang Ideologi Negara" (Uin Sunan Kalijaga Yogyakarta, 23 Juni), Hal. 4-5, Http://Digilib. Uin-Suka.Ac.Id/22453/1/08370014_Bab-I_Iv-Atau-V_Daftar-Pustaka.Pdf.

${ }^{29}$ Fadlurrahman Ashidqi, "The Problem of Secularism Doctrine," KALIMAH 12, no. 2 (September 15, 2014): p. 229, doi: 10.21111 / klm.v12i2.237. 
teachings so that they are relevant to the progress of the times. ${ }^{30}$ In the case of Indonesia, the perspective of liberalism is also rejected from the perspective of Islamic purification, conservatism, and antiliberalism. $^{31}$

These fundamentalists are very hostile to Muslim scholars who study their Islam in the West who prioritize empirical and sociohistorical approaches. Meanwhile, fundamental Islam studies Islam in general normatively and textually. ${ }^{32}$ Everything that the Prophet had never done during his life, especially like this 4.0 era, was considered heresy, even though some of them were in it. Islam fundamentalist fanatical towards religion is usually very exaggerated and tends to shut itself off from other views and consider views that differ from them as wrong or heretical views. ${ }^{33}$ Usually this group limits the association, those who do not agree with it will be avoided even more violently they will deny it.

Responding to the doctrine and religious reality of these liberal and fundamental circles cannot be black and white, wrong or right, because each also has advantages and disadvantages. Fundamentalists are more dominant in studying Islamic sciences by memorizing books written by certain classical scholars, while liberalists in understanding Islamic science are more interested in contemporary scholars. It is not imaginary when fundamentalists face a reality that is not in accordance with the doctrine which tends to easily 'disbelieve' and / or consider the matter to be a heresy. As for liberalists in facing realities that are not in accordance with religious doctrine, they understand it by adjusting a case to the current context,

${ }^{30}$ Badarus Syamsi, "Perbedaan Corak Pemahaman Agama Antara Fundamentalisme Dan Liberalisme Serta Dampaknya Bagi Timbulnya Konflik Keagamaan," Al-Tahrir: Jurnal Pemikiran Islam 14, No. 1 (May 1, 2014): 73, Doi:10.21154/Al-Tahrir.V14i1.120.

${ }^{31}$ Akh. Muzakki, "Current Debates in the Post-Soeharto Indonesian Islam: Examining the Intellectual Base of Liberal and Anti-Liberal Islamic Movement," Al-Jami'ah: Journal of Islamic Studies 45, no. 2 (December 28, 2007): 321-66, doi: 10.14421 / ajis.2007.452.321-366.

${ }^{32}$ Stephen M. Feldman, ed., Law and Religion: A Critical Anthology, Critical America (New York: New York University Press, 2000), pages 319-321. HE Chehabi, "Society and State in Islamic Liberalism," State, Culture, and Society 1, no. 3 (1985): 85-101.

${ }^{33}$ Muchlis M Hanafi, Moderasi Islam (Menangakal Radikalisasi Berbasis Agama) (Kertamukti: PSQ, 2013), hal. 16, http://opac.ushuluddin.uinjkt.ac.id//index. php?p=show_detail\&id=8444. 
and sometimes even understanding Islamic teachings are slightly out of the corridors of sharia.

In addition, liberalists are usually more likely to be individualized in public life and their attitude towards an ordinary teacher. Any information or doctrine taught by a teacher must be reviewed by analyzing it according to the prevailing reality. These circles do not easily believe in doctrinal or normative knowledge, let alone that doctrine is mixed with myths. A critical approach is always put forward. Therefore, many innovations and knowledge derivations were generated from these liberals when the information received was not in accordance with current realities. As an epistemological description, the difference between the doctrine and reality of Islamic fundamentalism is identical to the ideological mode, while liberal Islam is identical with the academic mode. ${ }^{34}$

According to the Liberal Islam group, the reading and efforts of the classical mufassirin towards the text (nas\}) still prioritize the understanding of the text that comes from the reader (the reader / himself), so that it seems that there is a deviation (mastery of the truth of the text from the absolute which is "unlimited" by those who "limited" reader). So from here reading a text (nas\}), hermeneutics is needed. The Liberal Islam movement seeks to capture the meaning of the text by "avoiding arbitrary interpretation" - which in their eyes - often occurs and is carried out by individuals or groups of people who limit God's will (the will of divine) or the deepest desires of the meaning of the text by provides a final limit and is the final result of the will of the text which cannot be denied and contested.

The position of the narrative shar ' $i$ or let's call it the Qur' an and the sunnah nabawiyyah among fundamentalists is very significant. $N a s\}$ for fundamentalists is a "living" message, what is written must be carried out and done in the realm of life as it is stated: "Those whom We have given him the Bible, they read it with the actual reading [do not change and interpret as they like, they believed in him. and whoever denies to him, Then they are the people who lose (al-Baqarah: 121) and its application in life as in one of the contents of the Qur'an: "This is a book that we send to you full of blessings so

${ }^{34}$ Caroline Cox, John Marks, and Institute for the Study of Civil Society, The "West", Islam and Islamism: Is Ideological Islam Compatible with Liberal Democracy? (London: Civitas, Institute for the Study of Civil Society, 2003), p. 27-28. 
that they pay attention to His verses and in order to get a lesson from those who have thoughts (Surah Șād: 29). ${ }^{35}$

The perspective of the two schools of thought described above which is supported by the development of digital technology shows that there is an epistemological dynamic that will never finish. The two of them continue to compete by spreading ideas and carrying out real movements to fight for influence in society, the impact of which is the occurrence of polarization. However, in this case the writer argues that the two perspectives do not always conflict. There are Muslim groups that are able to reconcile or synthesize epistemological dynamics as well as religious ways which are always considered to be conflicts. This is called a hybrid of thought, and in Indonesia like this has developed. So the dynamics of thinking that are always face to face are always accompanied by thoughts that try to bring them together.

\section{HYBRID RELIGIOUS THOUGHT IN INDONESIA}

It should be noted that in the contemporary context, Islamic thought cannot be seen in black and white. The school of thought described earlier shows face to face which makes it impossible to meet in a person or a group. However, this section wants to emphasize that not always people who understand fundamentalism will reject liberalism or vice versa, including other religious schools of thought. This kind of person has a hybrid thinking character. This character of thought seeks to find common ground between things that are always contradictory and then tries to integrate them. Hybrid thinking is often used by scientists from various disciplines who seek to find common ground for differences. For example, what happens in the discipline of psychology which seeks to find common ground from differences related to the factors that influence delusional beliefs. ${ }^{36}$ In the same philosophical discipline, hybrid logic is said to be better

${ }^{35}$ Alamul Huda, "Epistemologi Gerakan Liberalis, Fundamentalis, Dan Moderat Islam Di Era Modern,” Journal De Jure 2, No. 2 (December 30, 2010), Doi:10.18860/ J-Fsh.V2i2.2977.

${ }^{36}$ Kengo Miyazono and Ryan McKay, "Explaining Delusional Beliefs: A Hybrid Model," Cognitive Neuropsychiatry 24, no. 5 (September 3, 2019): 335-46, doi:10.10 80/13546805.2019.1664443. 
at performing proofs than ordinary logic. ${ }^{37}$ Then what is the kind of hybrid religious thought that has developed? This section will explain it in the context of Indonesia.

Religious thoughts that were previously contrasting can also synthesize and complement each other. This is confirmed by Kersten in the work he wrote about the contestation of Muslim thought in Indonesia. ${ }^{38}$ Azra notes in commenting on the work which states that Muslim intellectuals who are categorized as traditionalists at the same time can also accept the modernist point of view. On the other hand, Muslim intellectuals who were originally categorized as modernists at the same time accept and appreciate the traditionalist point of view that holds true to the turast realm. They can no longer be said in isolation unrelated to any other thought. According to him, the dynamics in contemporary Indonesia cannot be separated from the dynamics of society, both domestically and globally. The contextualization and indiginization approach seems to be a trend by Indonesian Muslim intellectual circles. According to Kersten, ${ }^{39}$ In the realm of philosophy, post-modernism is the last (third) school of thought of the two previous schools, namely traditionalism (the first) and modernism (the second).

There is a lot of other evidence that points towards it. Ahmad Najib Burhani's research attempts to describe the context of Muhammadiyah institutions. According to him, Muhammadiyah as a religious and community organization has been able to combine Islam and modernism. But on the other hand, in the theological context, a number of Muhammadiyah members are exclusive and puritanical, although some are religiously moderate. Two opposites that were previously considered unable to meet, in this case can meet their respective contexts. ${ }^{40}$

${ }^{37}$ Torben Braüner, "Why Does the Proof-Theory of Hybrid Logic Work so Well?," Journal of Applied Non-Classical Logics 17, no. 4 (January 2007): 521-43, doi:10.3166/jancl.17.521-543.

${ }^{38}$ Carool Kersten, Islam in Indonesia: The Contest for Society, Ideas and Values (London and New York: Hurst \& Co Publishers and Oxford University Press, 2015).

${ }^{39}$ Azyumardi Azra, "Kontestasi Pemikiran Islam Indonesia Kontemporer," Studia Islamika 23, no. 1 (July 26, 2016): 175-84, doi:10.15408/sdi.v23i1.2905.

${ }^{40}$ Ahmad Najib Burhani, "Pluralism, Liberalism, and Islamism: Religious Outlook of Muhammadiyah," Studia Islamika, December 1, 2018, 433-70, doi: 10.15408 / sdi.v25i3.7765. 
When examining the backward discourse, there are two terms that describe the above understanding, namely "neo modernism" and "post traditional". The two terms are basically the same spirit, but they have differences. Neo modernism is able to attract attention from modernists as well as traditionalists, but its thought base is dominated by a modernist perspective. The majority is supported by academics. It is different from post-traditionalism whose supporters come from traditionalist circles. They see that the worldview of neo-modernism misses out on their intellectual traditions. This posttraditionalism group seeks to reconcile the basis of their intellectual tradition with philosophical theories, social sciences, field studies, advocacy and others. Not only from among students or scholars, the traditional pesantren also joined this group. These two groups are not groups of fundamentalism or liberalism, but groups that have mixed, merged and integrated from various religious thoughts.

Post-traditionalism is based on the dynamics of a local context that is not pressurized from abroad and interacts openly with various societies, religious currents, and all existing world views. Although they are different between neo-modernism and post-traditionalism, both of them have the same attention to contemporary humanitarian issues and Indonesian issues. Then they emphasized the importance of political tolerance, upholding law and human rights, and developing social organizations. Although they are different between neo-modernism and post-traditionalism, both of them have the same attention to contemporary humanitarian issues and Indonesian issues. Then they emphasized the importance of political tolerance, upholding law and human rights, and developing social organizations. Although they are different between neo-modernism and post-traditionalism, both of them have the same attention to contemporary humanitarian issues and Indonesian issues. Then they emphasized the importance of political tolerance, upholding law and human rights, and developing social organizations. ${ }^{41}$ In this context the terms neo modernism and post traditionalism are used to describe synthetic thoughts.

${ }^{41}$ Abdul Ala, "Niqāt Al-Iltiqā 'Bayn Madhhad al-Tahdīth al-Jadīd Wa al-Ittijāh al-Taqlīdī al-Mutațawwir al-Judhūr al-Ma'rifiyah Li Madhhab al-Jawharīyah alIslāmīdī Wa Intishāruhī, Studīāruhīs, 11, no. 1 (April 30, 2004), doi: 10.15408 / sdi. v11i1.654. 
Another thought that is same with his character is Islam wasatiyyah. The Indonesian Ulama Council uses this term to consolidate the dynamics of Islamic thought which tends to be too right or too left. This idea has characteristics; taking the middle path (tawassut\}), continuous, straight and firm (i'tida $>l)$, tolerance (tasa>muh), egalitarian (musa>wah), prioritizing deliberation $(s h u>r a>)$, has the spirit of reform $(i s\} l a>h\})$, prioritizes the priority (aulawiyah), is dynamic and innovative (tat $\}$ awwur wa ibtika $>r$ ), and is civilized (tahad\} $d\}$ ur). ${ }^{42}$ Meanwhile, the Indonesian government, through the Ministry of Religion, did not remain silent. It is the term that he has developed is religious moderation which is the middle way of all schools of thought by publishing books in print and online which can be downloaded for free on the internet. ${ }^{43}$ The basics of this view (Islam wasat; iyyah) were also written by the foremost exegete in Indonesia, namely Quraih Shihab who wanted to emphasize that Islam is moderate. ${ }^{44}$

The hybrid form of thought that has been described is a response to the dynamics of Islamic thought today which are always face to face. This characteristic of thinking seeks to find a middle way, conduct a synthesis, take the good from existing thoughts, be more objective and accommodate differences. The position of the synthesis or hybrid of this thought can be seen, for example, in understanding religion using both textual and contextual methods that involve rationality and intuition. The previous traditions and the modern traditions are equally upheld (accommodated) while they are still relevant or not contradicting with religious values. Both classical and contemporary sources of knowledge are used in understanding religious teachings.

Once again, this way of thinking in Indonesia is not sudden but has gone through a long history of Islam in Indonesia. ${ }^{45}$ Although the hybrid way of thinking already exists and even becomes the majority in Indonesia, the dynamics of conflicting thinking previously

${ }^{42}$ Taujihat Surabaya, the IXth Indonesian Ulema Council (MUI) National Conference which was held on 08-11 Dzul Qa'dah 1436 H / 24-27 August 2015.

${ }^{43}$ Tim Penyusun Kemenag RI, Moderasi Beragama (Jakarta: Balitbang Diklat Kemenag RI, 2019).

${ }^{44}$ M. Quraish Shihab, Wasathiyyah Wawasan Islam Tentang Moderasi Beragama (Tangerang: Lentera Hati, 2019).

${ }^{45}$ Irham Irham, "Bentuk Islam Faktual: Karakter Dan Tipologi Islam Indonesia," El-Harakah (Terakreditasi) 18, no. 2 (2016): 1-18, doi:10.18860/el.v18i2.3684. 
discussed are still growing. This means that in this case the dynamics of Islamic thought are very diverse and continue to grow forever. The world of education in this part contributes in shaping these various thoughts.

\section{THE ROLE OF ISLAMIC EDUCATION}

The growing religious school of thought cannot be separated from the role of Islamic education, although it is not the only one. Sociocultural and political aspects also contributed to the formation of religious schools.

Liberalism and its challengers, which are often referred to as anti-liberal or as a form of religious fundamentalism, are two schools of Islamic legal thinking. In the case of Indonesia, these two schools of thought were formed not only from the educational aspect but also from other aspects. The socio-cultural background that builds the epistemic community in urban areas is involved in creating this thought. Liberal Islamic thought patterns are formed from a combination of traditional and modern education in Islamic studies with other disciplines accompanied by the interaction of urban communities in urban areas. The characteristics of this liberal group are faced with the orientation of secular ideology. This means that the development of their Islamic understanding is carried out in a certain way which has the same frequency and is not like conventional preaching. With this, the developed liberal Islamic thought can continue to grow.

It is different from the anti-liberal group (fundamentalism group) which is formed from a traditional or modern learning without any combination which is strengthened by meeting with the urban Muslim community who have an ideological Islamic orientation. They are formed into an epistemic community as opposed to the liberal Muslim community. ${ }^{46}$ This explanation actually shows the same pattern between the formation of the two groups above. Both have a background from the world of education, then coupled with the joining of people who have the same orientation or have the same interest in these ideas and grow in the same community with

${ }^{46}$ Akh. Muzakki, "Is Education Determinant? The Formation Of Liberal And Anti-Liberal Islamic Legal Thinking In Indonesia, "Journal Of Indonesian Islam 1, no. 2 (December 1, 2007): 280, doi: 10.15642 / JIIS.2007.1.2.280-322. 
the same understanding. Educational background is the initial basis for the way of thinking of each group which can then determine the school of thought that must be followed, although this is not forever because one day they can move.

The form of education that gave birth to these two schools of thought has a contrasting teaching model and orientation. The educational model developed by the liberal Islamic group is said to be an academic model. This educational model is oriented towards the development and expansion of science, then uses a critical approach to make analyzes, presents various views of thought which then results in education (outcomes) to produce alumni or individuals who are autonomous and able to think independently. This education model is usually developed by religious education institutions / colleges (universities) with an orientation to the development of knowledge, or the development of students' skills. Meanwhile, the educational model developed by fundamentalist Islamic groups is called the ideological model. This model prioritizes studying the Qur'an, $\mathrm{h}$ adith, and classical Islamic sources as well as learning Arabic. The full authority that can explain or teach this knowledge is the scholar or the teacher. Critical reasoning is certainly not taught here. The purpose of this approach is to produce devout Muslims who reject the criticism of students. ${ }^{47}$ The example of this educational model include madrasah or boarding school (Islamic education institutions) with a religious purification style (manhaj salafi) or other terms are haraki boarding school. ${ }^{48}$

The output produced from these two educational models has an impact on their social attitudes. The ideological education model tends to mingle with society and has extraordinary courtesy to the figure of a teacher who teaches Islamic science such as ustadz, kiai or habaib. This phenomenon can be seen how their respect for teachers is by kissing their hands to get blessings, removing their sandals when they are on a pilgrimage to the graves of sacred scholars or kiai, standing up and stopping while bowing to when they cross paths

${ }^{47}$ Cox, Marks, and Institute for the Study of Civil Society, The "West", Islam and Islamism, p. 27-28.

${ }^{48}$ Mukhibat Mukhibat, "Deradikalisasi Dan Integrasi Nilai-Nilai Pluralitas Dalam Kurikulum Pesantren Salafi Haraki Di Indonesia," Al-Tahrir: Jurnal Pemikiran Islam 14, no. 1 (May 1, 2014): 181, doi:10.21154/al-tahrir.v14i1.121. 
with teachers. The teacher's authority and its authority in choosing science strengthen the legitimacy of its doctrine towards students. ${ }^{49}$

Actually, the ideological education model does not necessarily give birth to a fundamentalist way of being religious, but it can also create traditionalist or conservative groups. Each of these groups is different in character, because traditionalist and conservative groups do not have the doctrine of khilafahism or jihadism like fundamentalism. The educational model that leads to fundamentalism can be said to be an ideological-purification education model. This model seeks to limit reading material, and to provide books that can be read only. The doctrines of purification, khilafahism, jihadism are always there, and do not miss the doctrine of al-wala'nwa albarra'. This latter doctrine later became the seed of takfiri ideology. Basically, the aspect of the faith is the foundation of this educational model. The religious models born from this education are salafi puris, salafi $h$ \}araki, and salafi jihadi (who like to fight against different views). Another term for this model is the salafi manhaj education model. ${ }^{50}$ Islamic education in Indonesia which is oriented towards that direction (liberalism or fundamentalism) certainly exists, although not much, because this group is still a minority.

Furthermore, related to hybrid thinking, it is also developed in the world of Islamic education. Islamic boarding school education, although it varies including the existence of the h\}araki / manhaj salafi boarding school, but in general (mainstream) this education is recognized as capable of producing moderate-inclusive diversity as a character of hybrid thinking. This education can be seen as enlightening the socio-cultural context and can also be influenced by social realities such as the development of fundamentalism and religious liberalism. The principles inherent in it are togetherness, justice / balance, tolerance which leads to social liberation. Basically, the dynamics of this education cannot be separated from the developing social factors. The role of this pesantren has occurred

${ }^{49}$ Mohammad Muchlis Solichin, "Interrelation of Kiai Authorities, Curriculum and Learning Culture in Indonesian Pesantren," Tarbiya: Journal of Education in Muslim Society 5, no. 1 (October 21, 2018): p. 87-100, doi: 10.15408/tjems.v5i1.7781.

${ }^{50}$ Irham Irham, "Pesantren Manhaj Salafi: Pendidikan Islam Model Baru Di Indonesia," Ulul Albab Jurnal Studi Islam 17, no. 1 (May 25, 2016): 1-18, doi:10.18860/ ua.v17i1.3252. 
since several centuries ago which has since become a local wisdom as a moral fortress of society on socio-religious issues. ${ }^{51}$

Kyai Sahal Mahfudh, who is a representative of pesantren people, has emphasized that pesantren is the meeting point of various Islamic schools of thought, especially thoughts of jabbariah and qadariah faith. The majority of pesantren caregivers have a clear understanding the next Aswaja (ahlun al-sunnah wa al-jama> 'ah) which colors the Islamic style of the pesantren. The aswaja style of thought is a middle way. However, the main purpose of the pesantren is not to create a flow of aswaja from its founding figures but to create an active Islamic personality. ${ }^{52}$ Thus the pesantren is very open and becomes a meeting point for existing Islamic thoughts that are considered opposites. The principle inherent in pesantren is al-muh\} $a>f a d\} a h$ 'ala $>$ qadi $>m$ al-s\}a $>l i h\}$, wa al-akhdhu bi al-jadi $>d$ al$a s\} l a h\}$ including the principle of this meeting point (the principle of hybrid thought). According to Lukens Bull, pesantren are able to bring together tradition and modernity. ${ }^{53}$

The explanation above emphasizes that Islamic education is a strong aspect to form a religious typology including the dynamics of contemporary Islamic thought that has been previously described. It should also be underlined that the styles of Islamic education vary in orientation and teaching models. In the author's opinion, the hybrid model is certainly interesting to be explored further, which in turn can give birth to hybrid religious thinking and patterns.

\section{CONCLUSION}

The dynamics of contemporary Islamic thought have various styles, but have the same character. The character is a form of thought that is face to face (hostile) then there is a form of thought that synthesizes the various thoughts that exist (hybrid thought). This

${ }^{51}$ Ahmad Fauzi, "Konstruksi Model Pendidikan Pesantren: Diskursus Fundamentalisme Dan Liberalisme Dalam Islam," Al-Tahrir: Jurnal Pemikiran Islam 18, no. 1 (June 11, 2018): 85, doi:10.21154/altahrir.v18i1.1161.

${ }^{52}$ MA. Sahal Mahfudh, Pesantren Mencari Makna, ed. Marwan Ja'far, 1st ed. (Jakarta: Pustaka Ciganjur, 1999), 50-57.

${ }^{53}$ Ronald A. Lukens-Bull, "Two Sides of the Same Coin: Modernity and Tradition in Islamic Education in Indonesia," Anthropology html_ent Glyph = “ amp;" Ascii = "\& amp;" 7 Education Quarterly 32, no. 3 (September 2001): 350-72, doi: 10.1525 / aeq.2001.32.3.350. 
paper describes the opposite forms of religious thought, namely fundamentalism and liberalism. These two ideas are contradictory from various sides ranging from the basis of epistemology, ways or methods of understanding religion to religious models and when looking at the relationship between Islam and the nationstate and when responding to modernization / globalization. Then hybrid thought as a thought that takes a middle way and looks for common ground, its forms also vary; there are thoughts of postmodernism, neo-modernism, post-traditionalism, and moderate Islam (Islam wasat;iyyah). The characteristics of this thinking are open, objective, accommodative, integrative, looking for common ground, synthesizing, balanced and tolerant. The dynamics of contemporary Islamic thought are basically supported by the existing Islamic education model. Islamic fundamentalism is supported by the ideological-purist Islamic education model (manhaj salafi). Then the thought of Islamic liberalism is supported by academic, scientific, rational and secular educational models. The hybrid / moderate form of thought is supported by a moderate-inclusive education model that develops textual-contextual methods, balances nasal sources, reason and intuitions, accommodates old and modern traditions that are still relevant and not in conflict with religious values. Basically, a hybrid Islamic education model will always innovate without leaving rooted traditions. The next question is, which of the characteristics of thought described above are the types of Islamic thought and which Islamic education model is relevant in the digital era or the current 4.0 era? Future studies are certainly suggested to answer this question.

\section{REFERENCES}

A'la, Abd. "The Genealogy Of Muslim Radicalism In Indonesia: A Study Of The Roots And Characteristics Of The Padri Movement." Journal Of Indonesian Islam 2, No. 2 (December 1, 2008): 267-99. Doi:10.15642/Jiis.2008.2.2.267-299.

Ala, Abdul. "Niqāt Al-Iltiqā’ Bayn Madhhad Al-Taḥdīth AlJadīd Wa Al-Ittijāh Al-Taqlīdī Al-Mutațawwir Al-Judhūr Al-Ma'rifiyah Li Madhhab Al-Jawharīyah Al-Islāmīyah Wa 
Intishāruhāfī Indūnīsīyā." Studia Islamika 11, No. 1 (April 30, 2004). Doi:10.15408/Sdi.V11i1.654.

“Al-Shafi'I." In Wikipedia, July 31, 2020. Https:/En.Wikipedia. Org/W/Index.Php?Title=Al-Shafi\%E2\%80\%98i\&Old $\mathrm{id}=970506984$.

Anhusadar, La Ode. "Potensi Radikalisme Islam Fundamental Di Daerah Tujuan Wisata Di Kabupaten Wakatobi." Al-Tahrir: Jurnal Pemikiran Islam 18, No. 1 (May 30, 2018): 23-40. Doi:10.21154/Altahrir.V18i1.1122.

Ashidqi, Fadlurrahman. "Problem Doktrin Sekulerisme." Kalimah 12, No. 2 (September 15, 2014): 213. Doi:10.21111/Klm. V12i2.237.

'Asqalānī, Ibnu Hajar Al-. Tawālī Al-Ta 'Siss. Beirut: Dār Al-Kutub Al-'Ilmiah, 1986.

Azra, Azyumardi. "Kontestasi Pemikiran Islam Indonesia Kontemporer.” Studia Islamika 23, No. 1 (July 26, 2016): 17584. Doi:10.15408/Sdi.V23i1.2905.

Binder, Leonard. Religion And Politics In Pakistan. University Of California Press, 1961.

Braüner, Torben. "Why Does The Proof-Theory Of Hybrid Logic Work So Well?" Journal Of Applied Non-Classical Logics 17, No. 4 (January 2007): 521-43. Doi:10.3166/Jancl.17.521-543.

Buer, Sven-Vegard, Jan Ola Strandhagen, And Felix T. S. Chan. "The Link Between Industry 4.0 And Lean Manufacturing: Mapping Current Research And Establishing A Research Agenda." International Journal Of Production Research 56, No. 8 (April 18, 2018): 2924-40. Doi:10.1080/00207543.201 8.1442945 .

Burhani, Ahmad Najib. "Pluralism, Liberalism, And Islamism: Religious Outlook Of Muhammadiyah." Studia Islamika, December 1, 2018, 433-70. Doi:10.15408/Sdi.V25i3.7765.

Chalik, Abdul. "Fundamentalisme Dan Masa Depan Ideologi Politik Islam." Islamica: Jurnal Studi Keislaman 9, No. 1 (2014): 54. Doi:10.15642/Islamica.2014.9.1.54-80. 
Chehabi, H. E. "Society And State In Islamic Liberalism." State, Culture, And Society 1, No. 3 (1985): 85-101.

Cox, Caroline, John Marks, And Institute For The Study Of Civil Society. The "West", Islam And Islamism: Is Ideological Islam Compatible With Liberal Democracy? London: Civitas, Institute For The Study Of Civil Society, 2003.

Dahlan, Abdul Aziz. Pemikiran Falsafi Dalam Islam. Jakarta: Djambatan, 2003.

Dewi, Erowati. "Islam Liberal Di Indonesia (Pemikiran Dan Pengaruhnya Dalam Pemikiran Politik Islam Di Indonesia." Jiip: Jurnal Ilmiah Ilmu Pemerintahan 2, No. 2 (January 23, 2018): 18-32. Doi:10.14710/Jiip.V2i2.2119.

Fauzi, Ahmad. "Konstruksi Model Pendidikan Pesantren: Diskursus Fundamentalisme Dan Liberalisme Dalam Islam." Al-Tahrir: Jurnal Pemikiran Islam 18, No. 1 (June 11, 2018): 85. Doi:10.21154/Altahrir.V18i1.1161.

Feldman, Stephen M., Ed. Law And Religion: A Critical Anthology. Critical America. New York: New York University Press, 2000.

Hanafi, Muchlis M. Moderasi Islam (Menengakal Radikalisasi Berbasis Agama). Kertamukti: Psq, 2013. Http:// Opac.Ushuluddin.Uinjkt.Ac.Id//Index.Php?P=Show Detail\&Id=8444.

Hannabuss, Stuart. "Historical Dictionary Of Islamic Fundamentalism (2nd Edition)." Reference Reviews 32, No. 7/8 (September 17, 2018): 10-12. Doi:10.1108/Rr-09-2018-0133.

Hilmy, Masdar. "The Configuration Of Radical Islamism In Indonesia: Some Contemporary Assessments And Trajectories." Al-Tahrir: Jurnal Pemikiran Islam 14, No. 1 (May 1, 2014): 1. Doi:10.21154/Al-Tahrir.V14i1.84.

Hm, Sahid. "Contesting Caliphate: Opposition Of Indonesian Fundamentalist Groups To Isis Caliphate." Journal Of Indonesian Islam 8, No. 2 (December 1, 2014): 185-208. Doi:10.15642/Jiis.2014.8.2.185-208. 
Huda, Alamul. "Epistemologi Gerakan Liberalis, Fundamentalis, Dan Moderat Islam Di Era Modern.” Journal De Jure 2, No. 2 (December 30, 2010). Doi:10.18860/J-Fsh.V2i2.2977.

Husaini, Adian, And Nuim Hidayat. Islam Liberal: Sejarah, Konsepsi, Penyimpangan, Dan Jawabannya. Jakarta: Gema Insani Pres, 2002.

Iqbal, Asep Muhammad, And Zulkifli Zulkifli. "Islamic Fundamentalism, Nation- State And Global Citizenship: The Case Of Hizb Ut-Tahrir." Indonesian Journal Of Islam And Muslim Societies 6, No. 1 (June 1, 2016): 35. Doi:10.18326/ Ijims.V6i1.35-61.

Irham, Irham. "Bentuk Islam Faktual: Karakter Dan Tipologi Islam Indonesia." El-Harakah (Terakreditasi) 18, No. 2 (2016): 1-18. Doi:10.18860/El.V18i2.3684.

_. "Pesantren Manhaj Salafi: Pendidikan Islam Model Baru Di Indonesia." Ulul Albab Jurnal Studi Islam 17, No. 1 (May 25, 2016): 1-18. Doi:10.18860/Ua.V17i1.3252.

Jainal. "Polemik Metode Pemikiran Islam Fundamental Dan Liberal Tentang Ideologi Negara.” Uin Sunan Kalijaga Yogyakarta, 23 Juni. Http://Digilib.Uin-Suka.Ac.Id/22453/1/08370014_ Bab-I_Iv-Atau-V_Daftar-Pustaka.Pdf.

Jawzi, Ibn Al-. Manaqib Al-Imam Ahmad Bin Hambal. Mișr: Maktabat Al-Khānjī, 1979.

Kazmi, Zaheer. "The Limits Of Muslim Liberalism." Muslim Institute. Accessed May 22, 2020. Https:/Musliminstitute.Org/ Freethinking/Religion/Limits-Muslim-Liberalism.

Kemenag Ri, Tim Penyusun. Moderasi Beragama. Jakarta: Balitbang Diklat Kemenag Ri, 2019.

Kersten, Carool. Islam In Indonesia: The Contest For Society, Ideas And Values. London And New York: Hurst \& Co Publishers And Oxford University Press, 2015.

Lee, Yee Lak Elliot. "Behaviorist Fundamentalism Turns Radical: Etim/Tip's Islamic Fundamentalist Representations And Narratives." Journal Of Middle Eastern And Islamic Studies (In 
Asia) 9, No. 4 (December 2015): 85-99. Doi:10.1080/1937067 9.2015.12023274.

. "Behaviorist Fundamentalism Turns Radical: Etim/Tip's Islamic Fundamentalist Representations And Narratives." Journal Of Middle Eastern And Islamic Studies (In Asia) 9, No. 4 (December 2015): 85-99. Doi:10.1080/19370679.2015.1202 3274 .

Lukens-Bull, Ronald A. "Two Sides Of The Same Coin: Modernity And Tradition In Islamic Education In Indonesia." Anthropology $<H t m l$ Ent Glyph="@Amp;"Ascii="\&Amp;"> Education Quarterly 32, No. 3 (September 2001): 350-72. Doi:10.1525/ Aeq.2001.32.3.350.

Mahfudh, Ma. Sahal. Pesantren Mencari Makna. Edited By Marwan Ja'far. 1st Ed. Jakarta: Pustaka Ciganjur, 1999.

Miyazono, Kengo, And Ryan Mckay. "Explaining Delusional Beliefs: A Hybrid Model." Cognitive Neuropsychiatry 24, No. 5 (September 3, 2019): 335-46. Doi:10.1080/13546805.2019.1 664443.

Mukhibat, Mukhibat. "Deradikalisasi Dan Integrasi Nilai-Nilai Pluralitas Dalam Kurikulum Pesantren Salafi Haraki Di Indonesia." Al-Tahrir: Jurnal Pemikiran Islam 14, No. 1 (May 1, 2014): 181. Doi:10.21154/Al-Tahrir.V14i1.121.

Munjid, Achmad. "Militant And Liberal Islam: The Unwanted Twin Children Of Modernization Â" An Indonesian Experience." Journal Of Indonesian Islam 3, No. 1 (June 1, 2009): 35. Doi:10.15642/Jiis.2009.3.1.35-68.

Muzakki, Akh. "Current Debates In The Post-Soeharto Indonesian Islam: Examining The Intellectual Base Of Liberal And AntiLiberal Islamic Movement." Al-Jami'ah: Journal Of Islamic Studies 45, No. 2 (December 28, 2007): 321-66. Doi:10.14421/ Ajis.2007.452.321-366. And Anti-Liberal Islamic Legal Thinking In Indonesia." Journal Of Indonesian Islam 1, No. 2 (December 1, 2007): 280. Doi:10.15642/Jiis.2007.1.2.280-322. 
Oray, Anita. "Religious Fundamentalism And Radicalization," March 2015. Https://Www.Europarl.Europa.Eu/Eprs/ Eprs-Briefing-551342-Religious-Fundamentalism-AndRadicalisation-Final.Pdf.

Pipes, Daniel. In The Path Of God: Islam And Political Power. New Brunswick, N.J: Transaction Publishers, 2002.

Rajihi, Abdul Aziz Al-. Syarh Usul Al-Sunnah Li Imam Ahmad Bin Hamal. Riyad: Dar Tauhid, 1433. Https://Www.Noor-Book. Com/كتاب-شرح-أصول-السنة-للإمام-أحمد-بن-حنبل-Pdf-Pdf.

Rumi, Yaqut Al-Hamawi Al-. Mu 'Jam Al-Udabā: Irsyad Al Arif Ila Ma'rifati Al-Adib. Beirut: Dar Gharbi Al-Islami, 1993. Http:// Archive.Org/Details/Waq45344.

Shihab, M. Quraish. Wasathiyyah Wawasan Islam Tentang Moderasi Beragama. Tangerang: Lentera Hati, 2019.

Solichin, Mohammad Muchlis. "Interrelation Kiai Authorities, Curriculum And Learning Culture In Pesantren Indonesia." Tarbiya: Journal Of Education In Muslim Society 5, No. 1 (October 21, 2018). Doi:10.15408/Tjems.V5i1.7781.

Syamsi, Badarus. "Perbedaan Corak Pemahaman Agama Antara Fundamentalisme Dan Liberalisme Serta Dampaknya Bagi Timbulnya Konflik Keagamaan." Al-Tahrir: Jurnal Pemikiran Islam 14, No. 1 (May 1, 2014): 73. Doi:10.21154/Al-Tahrir. V14i1.120.

Wahid, Din. "Nurturing The Salafy Manhaj: A Study Of Salafi Pesantrens In Contemporary." Utrecht University, 2014. 